\title{
VIABILITAS RAGAM HIAS SULUR GELUNG TERATAI
}

\author{
Akhmad Nizam¹ (amigonizam@yahoo.com, Institut Seni Indonesia Yogyakarta)
}

\begin{abstract}
The walls of Hindu and Buddhist temples in Java are often found in the carved ornament of lotus plants that is grown from tubers or urns. In early period of Islam in Java, the existence of this decorative variety remained. Based on the books of the Hindu Purana, there is an explanation of the concept of the the universe creations embodied in the form of lotus scrolls. Meanwhile, from the old manuscripts belonging to the Wali, although limited in the scope of Sufism of the Tarekat Syaththariyah there is an explanation of the lotus with the name of the Tunjung flower. This article discusses the concept of creating works of art based on the theory of adaptation by Linda Hutcheon in his book: A Theory of Adaptation. The discussion is more emphasized on the visual aesthetic aspects contained in Lara Jonggrang Prambanan temple in Kalasan Yogyakarta, Surowono Temple in Kediri East Java and Sunan Drajat tomb in Lamongan, East Java. The ornamental variety, whose concept of creation was adapted from Purana books of Hindu, was in early Islam believed to follow the theoretical procedures, as well as in later times, but the philosophical meaning may be less well known.
\end{abstract}

Keywords: ornament, sulur gelung, padmamūla, tunjung

\section{ABSTRAK}

Dinding candi-candi Hindu dan Buddha di Jawa, sering ditemukan pahatan ragam hias sulur tumbuhan teratai yang tumbuh dari bonggol atau guci bergelung-gelung. Pada masa Islam awal, eksistensi ragam hias ini tetap bertahan. Berdasarkan kitab-kitab Purana Hindu, terdapat penjelasan mengenai konsep pembentangan alam semesta yang diwujudkan dalam bentuk gulungan teratai. Sementara itu, dari naskah lama milik para Wali, meskipun terbatas dalam lingkup tasawuf Tarekat Syaththariyah terdapat penjelasan mengenai teratai dengan nama bunga tunjung. Artikel ini membahas tentang konsep penciptaan karya seni berdasarkan teori adaptasi oleh Linda Hutcheon dalam bukunya: A Theory of Adaptation. Pembahasan lebih ditekankan pada aspek-aspek estetis visual yang terdapat di candi Lara Jonggrang Prambanan di Kalasan Yogyakarta, Candi Surowono di Kediri Jawa Timur dan makam Sunan Drajat di Lamongan Jawa Timur. Ragam hias tersebut, yang konsep penciptaannya diadaptasi dari kitab-kitab purana Hindu, maka pada masa Islam awal diyakini mengikuti prosedur teori tersebut, begitu juga pada masa berikutnya, tetapi makna filosofisnya mungkin kurang begitu dikenal.

Kata kunci: ragam hias, sulur gelung, padmamūla, tunjung

\section{PENDAHULUAN}

Ragam hias yang dipahatkan pada bangunan suci candi Hindu-Buddha, masjid dan makam Islam, daya hidupnya (viability) sepenuhnya diabdikan untuk memenuhi kebutuhan religius, sifatnya terpakai, dilakukan dengan rasa hormat dan gagasan penciptaannya terikat dari ajaran suci, namun 
visualisasinya terbuka kebebasan berekspresi bagi seniman. Konsep dan ide kebentukan ragam hias berangkat dari alam yang diidealisasi, disesuaikan dengan cita-cita keindahan manusia. Keindahan alam (pesona bentuk) yang diaktualisasikan bukan keindahan alami yang konkrit, tetapi sudah distilisasi. Stilisasi merupakan penggubahan bentuk-bentuk di alam dalam seni menjadi bentuk-bentuk artistik atau gaya tertentu. Terkait dengan kata gaya, maka stilisasi disebut juga "penggayaan".

Terdapat bermacam-macam gaya ragam hias, penyebarannya menurut Hoop terbagi menjadi dua. Pertama secara difusi, yaitu dari satu pusat kemudian menyebar. Kedua secara elementargedanken, yaitu adanya kesamaan fikiran dari manusia di belahan bumi yang berjauhan (1949: 9). Elementargedanken merupakan pemikiran yang muncul secara serentak atau hampir bersamaan dalam wilayah yang berbeda, maka muncul gaya Jawa Tengah, gaya Jawa Timur dan gaya-gaya di seberang Laut Jawa yang non-Hindu, karena tidak terpengaruh India, berbeda dengan gaya Jawa-Bali yang kental dengan warna India (Soedarso, 2006: 84). Sedangkan gaya Jawa Tengah, karena dedikasi dan kecintaannya terhadap seni hias yang diwarisi secara turun-temurun, maka tidak akan dibiarkan sebilah kayu polos tanpa ukiran (Muchtar, 1991: 9). Sebuah ragam hias dikatakan telah memiliki gaya tertentu, jika sudah mengalami pembakuan dalam waktu yang lama, tidak berubah dan konstan. Ragam hias tersebut memiliki corak normatif yang khas, yang menjadi ciri khususnya.

Konsep penciptaan ragam hias sulur gelung teratai $(p a d m \bar{a})$ diadaptasi dari ajaran kosmogoni Hindu mengenai penciptaan alam semesta. Konsep yang secara tematik berasal dari Hindu ini, ternyata diterapkan juga di candi-candi Buddha, bahkan diimplementasikan di masjid dan makam Wali Islam. Sebenarnya ragam hias padmā tidak lazim atau bukan dari khasanah kebudayaan Islam. Seni islamis memiliki konsep yang berbeda dengan Hindu-Buddha. Hampir semua peneliti mengondisikan dan memekatkan seni hias Islam identik dengan gaya, jenis, dan identitas wilayah Arab, yaitu gaya Arabesque-Arabeska, tetapi gaya ragam hias Islam awal (masa transisi) di Jawa, dipastikan tidak mengikuti gaya Arabeska.

Joseph Fischer, dalam The Folk Art of Java, setelah meneliti kebudayaan Jawa menyimpulkan, bahwa ada tiga aspek penting untuk mengkaji seni dan budaya Jawa di masa lampau, yaitu myth, ritual, symbol (1994: 2) Antara mitos, ritual dan simbol-simbol kepercayaan terjalin kuat dalam kesenian rakyat, sehingga untuk membuat perbedaan diantaranya sangat sulit. Bahkan diantara ketiganya telah melebur menjadi satu kesatuan, misalnya: terdapat tokoh figur wayang Jawa disandingkan dengan kaligrafi Arab; gambar tokoh dalam kisah dakwah Wali; teks kaligrafi Arab berdampingan dengan aksara Jawa; bouraq (binatang khayal); kaligrafi Arab dalam bentuk tokoh Semar; mitos Ratu Kidul. Tema-tema tersebut menunjukkan konteks pendidikan dan pembelajaran yang berhubungan dengan fiturfitur penting sejarah dan budaya Jawa. Hal ini sekaligus menepis anggapan "particularly to that which has been incorrectly termed the 'little tradition' "( Fischer, 1994: 38). Sikap Islam yang inklusif terhadap simbol-simbol budaya, tentu melibatkan tradisi intelektual dan spiritual yang dinamis dan kreatif.

Linda Hutcheon dalam $A$ Theory of Adaptation (2006: 7-8) mendefinisikan adaptasi sebagai proses menyesuaikan, mengubah, menyocokkan, membuat menjadi sesuai. Adaptasi merupakan pengulangan, namun bukan peniruan dan merujuk kepada tiga hal. Pertama, merupakan pemindahan suatu karya yang dikenal dari satu bentuk ke bentuk yang lain (process of transposition), transposisi dari satu karya ke karya lain. Kedua, sebagai proses kreatif (process of creation) yang melibatkan re-interpretasi dan re-kreasi. Proses adaptasi di dalamnya terdapat interpretasi ulang dan kreasi ulang. Ketiga, adaptasi pada dasarnya adalah sebagai sebuah cara melihat sebuah narasi dari sudut pandang yang berbeda.

Proses adaptasi membutuhkan kreativitas, improvisasi dengan konsep karya yang dapat menghidupkan kembali ide-ide 
yang masih relevan dengan situasi di tengah masyarakat. Konsep dapat dilihat sebagai teks, sedangkan karya adalah konteks. Teks dalam hal ini termasuk lingkungan, yang berhubungan dengan zaman sebagai konsep lahirnya konteks atau karya seni. Teks zaman ditangkap manusia untuk melahirkan konteks sebagai konsep dan tanda zaman (Sunarya, 2003: 199). Suatu karya seni bagaimanapun sederhananya pasti dilandasi oleh konsep, hanya segi kualitas yang membedakannya. Konsep penciptaan ragam hias sulur gelung teratai sejak zaman Hindu-Buddha sampai pada era Islam masa transisi sangat mungkin menggunakan metode adaptasi.

\section{PEMBAHASAN}

\section{a. Konsep Sulur Gelung Teratai dalam Kitab- Kitab Purana Hindu}

Baik pada candi-candi Hindu (Śaiva) maupun Buddha terdapat rangkaian ragam hias yang cukup mendominasi dinding dan langkan candi, yaitu rangkaian "sulur gelung" (Sedyawati, 2014: 522). Sulur gelung tersebut tidak lain adalah gubahan sulur-sulur teratai atau padmā. Brandes menamakannya ragam hias pilin tegar atau recal citrant (Hoop, 1949: 272). Ragam hias sulur gelung teratai secara tematik diadaptasi dari konsep kosmogoni Hindu tentang proses pembentangan alam semesta berdasarkan kitab Weda-samhita, yang berarti kumpulan kitab Weda. Kitab Purana memiliki kedudukan sebagai sarana untuk memahami Weda (Wid=tahu), yaitu pengetahuan akan Tuhan (Hadiwijono, 1971: 17).

Dijelaskan dalam kitab Brahma Purana, bahwa pada mulanya di mana-mana yang ada hanyalah air dan Brahman (esensi keTuhanan) tertidur di atas air dalam wujud Vişnu. Karena air nama lainnya adalah nara dan tempat tidur disebut ayana, maka Vişn, yang tidur di atas air disebut Náráyańa. Dari dalam air muncullah telur keemasan, kemudian dari telur itu lahirlah Brahma. Brahma menciptakan diri-Nya sendiri, maka dikenal dengan nama Svayambhu, berasal dari kata bhu (terlahir) dan svayam (oleh dirinya sendiri). Selama satu tahun penuh Brahma tinggal di dalam telur itu, kemudian Brahma memecahkan telur menjadi dua bagian. Brahma menciptakan sorga dan dunia dari pecahan telur tersebut (Donder, 2007: 154157).

Ringkasan penciptaan alam semesta menurut kitab Brahmánda Purána tidak jauh berbeda, bahwa pada awalnya tidak ada apaapa, dunia berada dalam keadaan yang gelap gulita. Dalam keadaan seperti itu Brahman (esensi ke-Tuhanan) ada di mana-mana. Alam semesta waktu itu hanya dipenuhi dengan air, dari dalam air itu muncul telur (anda) keemasan (hiranya). Dalam telur keemasan itu Brahma menciptakan diri-Nya sendiri (Svayambhu), dan karena rahim Brahma berupa telur keemasan, maka Brahma juga disebut Hiranyagarbha. Apa pun yang ada di dunia ini berasal dari kandungan Hiranyagarbha (Donder, 2007: 156-157).

Terdapat beberapa versi tentang dewa Brahma, bahwa Brahma dilahirkan dari Dewa tertinggi ketika bersekutu dengan Sakti nya, Maya. Ditempat lain dikisahkan, bahwa dewa Brahma diteteskan dari telur emas yang terapung-apung di atas air yang pertama. Kisah yang tersebar luas dan terkenal adalah, bahwa Brahma dilahirkan dari bunga lotus atau teratai yang keluar dari pusar Vişn, ini mula-mula bertiduran di lautan yang pertama di atas naga Sesa berkepala seribu. Ketika tertidur sebatang lotus atau teratai tumbuh dari pusarnya dan dari bunga lotus itulah dewa Brahma dilahirkan (Hadiwijono, 1971: 39-40).

Gagasan tentang asal mula kehidupan di perairan ini dituangkan dalam seni hias kosmologi air, dengan konsep bentuk gulungan teratai yang bergulung terusmenerus yang tumbuh dari akar rimpang berupa sulur-sulur daun dan bunga teratai. Gulungan teratai tesebut sering membingkai atau mendukung burung dan hewan. Pangkal tumbuh sulur gelung teratai biasanya muncul dari mulut atau pusar yaksa (Gambar 1a) atau simbol air yang lebih jelas, yaitu guci berlimpah (Gambar 1b) atau dari rahang terbuka Makara atau ekor ikan atau dari mulut gajah (Coomaraswamy, 1931: 3). Berdasarkan 
informasi dari teks-teks tersebut, terdapat beberapa hal yang patut diperhatikan, yaitu simbol binatang air, guci berlimpah dan teratai.

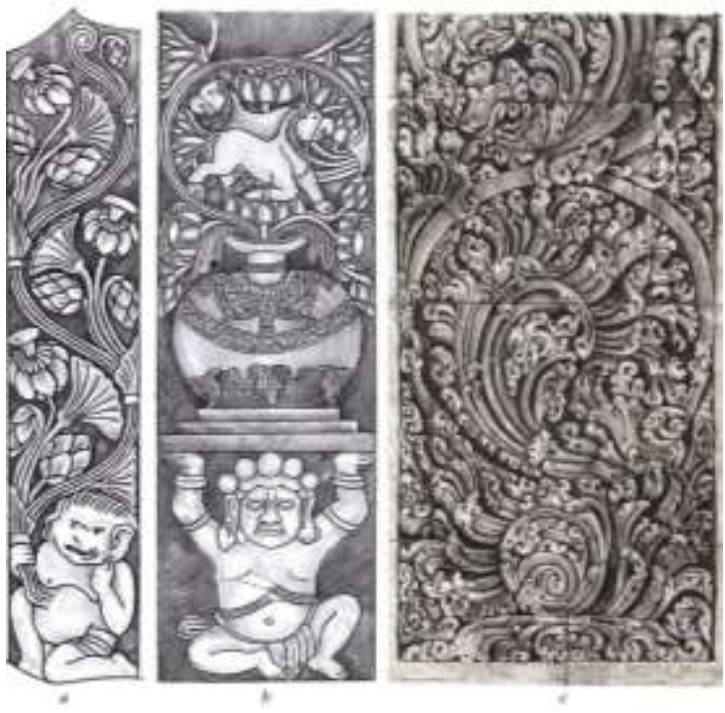

Gambar 1. Ragam hias sulur gelung teratai, $a$ : Altar Verandah, Bhājā, India; b: Amarāvati, India; c: Candi Lara Jonggrang Prambanan, a \& b dokumentasi

Coomaraswamy, 1931. (a-c Gambar tangan Nizam 2017, 2019)

Makara adalah binatang mitologi yang selalu dihubungkan dengan air. Menurut Sedyawati, karena benih kehidupan berada di air, maka sulur gelung teratai digambarkan tumbuh dari makhluk yang berasosiasi dengan air, seperti kepiting, ikan, gajah dan lain-lain (2014: 522-523). Mengenai yaksa, terdapat kemiripan penggambaran tokoh bhúta di Jawa dengan yaksa. Mungkin tokoh bhúta memiliki relasi dengan yaksa. Tokoh bhúta dalam kosmologi Hindu digambarkan gendut pendek, yang mendukung pilaster pada candi-candi Hindu maupun Buddha. Bhúta, menurut Sedyawati adalah makhluk lambang dunia bawah (Sedyawati, 1992: 2). Di Jawa lambang dunia bawah dihubungkan dengan ular atau air.

Teratai digambarkan memiliki sulur bercabang-cabang yang disejajarkan dengan percabangan terus-menerus dalam proses kehidupan, dari kelahiran yang satu ke kelahiran yang lain (Sedyawati, 2014: 523). Teratai pada tingkat makrokosmos, menjadi simbol seluruh dunia yang tercipta. Teratai yang tumbuh (keluar) dari pusar Vişņu menandai dimulainya penciptaan alam semesta, menggambarkan tumbuh dan berkembangnya dunia, kesuburan dan kehidupan yang berakar dan mengambil kekuatan dari air primordial, mewakili mekarnya kehidupan. Hoop mengutip pendapat Bosch, bahwa dalam khuluknya [karakter] teratai itu tidak memakai sulursulur. Tetapi dalam pelukisannya sering digambarkan pakai sulur-sulur. Sulur-sulur itu tidak dimaksud tangkainya, tetapi akar tinggal teratai yang menjalar dalam lumpur di bawah air. Akar tinggal ini mempunyai buku-buku [ruas-ruas] dengan jarak teratur, dan dari buku-buku tersebut tumbuh tangkai-tangkai daun dan bunga, inilah yang mempunyai arti sebagai lambang kesuburan (1949: 270).

Akar tinggal teratai sebagai pangkal tumbuh digambarkan seperti pentolan bulat telur mirip bola lampu, atau seperti biji permata atau berbentuk bonggol. Pangkal tumbuh dalam bentuk permata paling umum ditemui. Tidak hanya di India, di Jawa dan di tempat lain, teratai paling umum digambarkan tumbuh dari permata. Baik pentolan, biji permata atau bonggol yang menjadi pangkal tumbuh sulur gelung teratai tidak lain adalah "padmamūla", yaitu bagian utama dari tanaman teratai, yaitu "akar" dari bahasa Sanskerta "mūla" (Bosch, 1960: 42). Contoh menarik ragam hias padmamūla terdapat di candi Lara Jonggrang Prambanan dalam bentuk padmamūla pentolan (Gambar 1c).

Terakhir adalah guci berlimpah. Sepanjang sejarah seni India, guci berlimpah (pūrnakalaśa, pūrṇaghaţa dan lain-lain) menjadi simbol paling umum dari semua simbol keberuntungan dan kebahagiaan, sebagai pagar gaib yang digunakan secara merata oleh semua mazhab, terjadi tidak hanya di India, namun juga di luar India dan di Indonesia (Coomaraswamy, 1931: 61; Kempers, 1954: 21). Guci berlimpah, vas, jambangan atau mangkuk dapat menjadi pangkal tumbuh sulur gelung teratai, karena guci-guci tersebut berisi air kehidupan. Menurut Bosch, mangkuk yang memuntahkan sulur gelung teratai disebut pūrnakalaśa atau pūrnaghaţa atau amritaghaţa atau bhadraghaţa (Bosch, 1960:110). 
Sayang sekali informasi mengenai viabilitas ragam hias padmamūla di candicandi Jawa Timur sangat minim. Sedyawati menyebutkan, bahwa di candi Jago terdapat ragam hias "motif tunas muda" (rekal sitran) yang menghiasi pipi tangga berbentuk sikusiku, juga menghiasi dinding candi bersama motif geometris lainnya, diselang-seling motif binatang, terutama jenis binatang bulan śaśa (Sedyawati, et al., 2013: 287). Bagaimanapun sekilas informasi tersebut patut dilakukan pengamatan lebih lanjut, utamanya di candicandi pada periode Majapahit, seperti candi Jago dan candi Surowono.
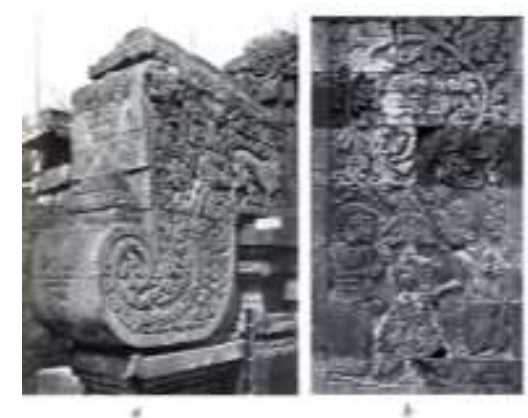

Gambar 2. a: Ragam hias sulur gelung candi Jago, dokumentasi Krom, 1923. (Foto repro Nizam 2019); $b$ \& $c$ : Relief Sri Tanjung candi Surowono, dokumentasi Kieven, 2013. (Foto repro Nizam 2019)

Ragam hias tunas muda di candi Jago, tidak lain adalah padmamūla yang tumbuh dari bonggol. Di sebelah bonggol terdapat binatang yang membelakangi, tetapi kepalanya menoleh garang, dua alis matanya seperti menyala. Dari bonggol tumbuh satu batang besar, pendek saja tetapi tegas membentuk simpul cantik yang pecah menjadi tiga cabang batang. Cabang batang tengah meneruskan batang di atasnya menjulur ke bawah mengisi pipi tangga siku (Gambar 2a).

Relief Sri Tanjung berkembang sepenuhnya di candi Surowono (Gambar $2 b$ \& $c)$, menceritakan tentang perselingkuhan yang naas, mempertanyakan kesetiaan seorang wanita yang mengalami cobaan berat termasuk kematian. Kisah ini populer pada masa Majapahit (Kinney, 2003: 235). Gambar 2b: menggambarkan Sidapaksa ketika mendapat tugas yang mustahil dan berbahaya, yaitu pergi ke surga dewa Indra. Gambar $2 c$ : fragmen Sri Tanjung ketika berada di gerbang surga dewa Indra ditolak masuk oleh Dorakala, penjaga alam arwah (Kieven, 2013: 244-245). Dipastikan yang menjadi latar belakang kedua relief tersebut adalah ragam hias padmamūla. Pangkal tumbuh padmamūla di candi Surowono dalam Gambar $2 b$ tidak teridentifikasi [rusak atau hilang], sedangkan dalam Gambar $2 c$ pangkal tumbuhnya terlihat jelas yaitu tumbuh dari bonggol bulat telur menyerupai vas. Penggambaran sulur gelung teratai padmamūla di kedua candi tersebut sangat berbeda gaya pelukisannya dengan sulur gelung Jawa Tengah yang bergulung penuh, cantik, rumit dan raya membentuk spiral.

\section{b. Konsep Teratai dalam Naskah Islam Jawa Pesisiran}

Teratai dalam naskah-naskah Islam Jawa Pesisiran disebut sebagai bunga tunjung yang digunakan sebagai perumpamaan. Akan tetapi perumpamaan yang mustahil, karena dalam redaksinya selalu disebut bunga tunjung yang tanpa telaga. Redaksi mengenai tunjung tanpa telaga terdapat dalam kitab Tariq Syaththariyah dari Gresik. Pada halaman 76 terdapat teks mengenai bunga tunjung beserta sarah atau keterangan dengan huruf miring (dalam tulisan ini, sarah diletakkan di antara tanda $\|\ldots\|$ ). Adapun petikan naskahnya sebagai berikut:

"Huruf kang tanpo aksoro \|Dzatullah\| segara tanpo tepi \|kamulyaning Allah\| papan tanpo tulis \|asmarabur tannono kawulo Gustill tunjung tanpo telogo \|roh idhofil"

"Huruf yang tiada aksara ||Dzat Allah\| laut tiada tepi ||Maha Mulya Allah\| papan tiada tulisan llasmara (cinta yang sudah menyatu) membaur kawula Gustill bunga teratai tanpa telaga ||ruh idhofi||"

Dijelaskan dalam kitab Bayan Alim hal. 33-35, yang ditemukan di Kranji, tidak jauh dari Drajat Paciran Lamongan Jawa Timur. Dalam teks naskah aslinya terbaca sebagai berikut: 
Wonten malih kang winardi, kandane ali murtala, saking njeng Nabi waune, sewu taun tan ngetung lintang, jempor ngideri jagad, wong ngangsu pikulan banyu, ngamek geni dadamaran.

Si cebol nggayuh langit, wrangka manjing curiga, randu alas mrambat pare, tanggal sepisan purnama, jukung layare arga, padati metu laut, baita amot segoro.

Tanpa pepantan tanpa tulis, kang tunjung tanpa telaga, pepitu pada tunggale, kang awas ujar punika, aja keliru tampa, si bisu mutusi padu, tilase kuntul nglayang.

Ada lagi yang menguraikan nasihat terkait dengan perumpamaan/ pepatah, kata Ali Murtala, yang asalnya dari Kanjeng Nabi, seribu tahun tidak mungkin dapat menghitung banyaknya bintang, akan menjadi lumpuh jika mengitari jagat raya, orang yang akan mencari sesuatu ilmu tentu saja sudah memiliki pengetahuan dasar akan ilmu yang akan dicarinya.

Orang kecil lagi pendek tidak mungkin akan mencapai/ menggapai langit, sarung keris tidak mungkin masuk pada kerisnya, pohon randu tidak mungkin akan merambat pada tumbuhan pare, baru tanggal satu tidak mungkin rembulan berbentuk bulat penuh, perahu kecil tidak mungkin berlayarkan gunung, tidak mungkin pedati/ gerobak melewati laut, tidak mungkin perahu memuat samodra/ laut.

Tanpa ada kelompok/ bagianbagiannya dan tanpa ada sesuatu pun, itu tidak mungkin dapat dihuni, bunga tunjung tidak ada telaga tidak mungkin akan hidup, dimana pun tentu saja terdapat angka tujuh, berhati-hatilah jika berbicara, jangan salah terima, sekalipun tidak bapat berbicara tetapi dapat menyelesaikan perang mulut, tidak mungkin ada bekas telapak kaki jika burung kuntul/ belibis sudah terbang.

Redaksi bunga tunjung tanpa telaga juga terdapat dalam kitab manuskrip anonim koleksi dari Rumah Ndalem, milik R. Edy Santosa keturunan Sunan Drajat ke-15. Adapun redaksi bunga tunjung terdapat dalam petikan naskah pada halaman 54, sebagai berikut:

"Sami ugo lan wangsit puniki, 'Tunjung ingkang datanpo telogo', Roh Idhofi sejatine, Dzatullah ananipun, punika sabdo kang rungsit, ciptane wong kang awas...

"Sama juga dengan sasmita (isyarat) ini, 'Teratai yang tanpa telaga', Ruh Idhofi yang sejati, Dzat Allah adanya, ini adalah sabda yang pelik, ciptaan orang yang awas [Makrifat] ....

Redaksi dalam naskah Bayan Alim, adalah perumpamaan-perumpamaan yang menggambarkan kemustahilan (kamokalan) dan berbagai ungkapan paradoks. Seumpama orang yang mengambil air dengan memikul air, mengambil api sambil membawa obor, tanggal satu sekaligus sudah purnama, atau seumpama perahu kecil tidak mungkin memiliki layar gunung atau kapal muatannya lautan. Ungkapan-ungkapan tersebut adalah gambaran keinginan seorang hamba untuk mempersatukan diri dengan sempurna kepada Tuhan adalah mustahil. Maka digunakan ungkapan mistik Jawa dengan berbagai paradoks yang juga mustahil. Menurut Zoetmulder ungkapan kang tunjung tanpa telaga (bunga padmā tanpa kolam) adalah padmā yang dapat tumbuh tanpa air yang biasanya merupakan sumber kehidupannya (2000: 338, 340). Bunga tunjung tanpa telaga adalah mokal karena tunjung akan binasa tanpa air kehidupan. 
Redaksi dalam petikan sarah kitab Tariq Syaththariyah ajaran Martabat Tujuh dan dalam naskah anonim menyebut "tunjung ingkang datanpa telaga" "padmā tanpa telaga" sebenarnya adalah "Ruh Idhafi, Dzat Allah Ada-Nya yang akan menghidupi padmā, jika padmā meninggalkan telaga. Sekali lagi, padmā dapat tumbuh (hidup) tanpa telaga yang menjadi sumber kehidupannya karena hidupnya akan dihidupi Dzat Allah, itu jika padmā meninggalkan telaga, meninggalkan lumpur tanah. Kang tunjung tanpa telaga kedudukannya tidak tergantung pada lumpur eksistensi dunia, artinya ragam hias teratai tersebut menggambarkan capaian spiritual dalam taraf yang sudah melampaui batasan dunia yang terbatas. Ungkapan-ungkapan di atas meskipun tampak paradoks, sebenarnya secara tersamar melukiskan hakikat kedudukan manusia sempurna (insan kamil) yang dianggap atau sebagai tamsil pantulan dari Dzat Mutlak. Keberadaannya sebagai bayang-bayang Tuhan, ibarat air sebagai penghubung antara laut dan ombak. Jadi, yang disampaikan dalam sasmita-sasmita di atas bukan kamokalan yang dituju, akan tetapi kemustahilan itu menjadi kenyataan. Yang terakhir, maqam Makrifat dalam naskah anonim (wong kang awas, yaitu orang yang memandang dalam taraf Makrifat) yang disejajarkan dengan sasmita tunjung ingkang datanpa telaga adalah kamokalan yang menjadi kenyataan atas restu Tuhan.

Sekarang, bagaimana konsep tunjung ingkang datanpa telaga di artikulasikan dalam ragam hias. Tentu saja bentuk ragam hias teratai atau tunjung yang tumbuh tidak dari telaga, yaksa, makara, berbagai simbol binatang air, pentol, bonggol atau berbagai bentuk guci berlimpah. Artinya tidak menggambarkan persis simbol padmamūla. Uniknya ragam hias gulungan teratai versi Islam masa transisi, konsep kebentukannya tetap mengacu simbol padmamūla, bahkan terlihat sama, akan tetapi pangkal tumbuhnya sengaja diganti atau disamarkan selain dari pangkal tumbuh yang sudah disebutkan di atas, yaitu tumbuh dari gundukan tanah berbatu-batu, bahkan tumbuh di atas gunung. Sekilas tampak sama, yaitu berupa gulungan teratai, tetapi nyata beda pangkal tumbuhnya (Gambar 3).

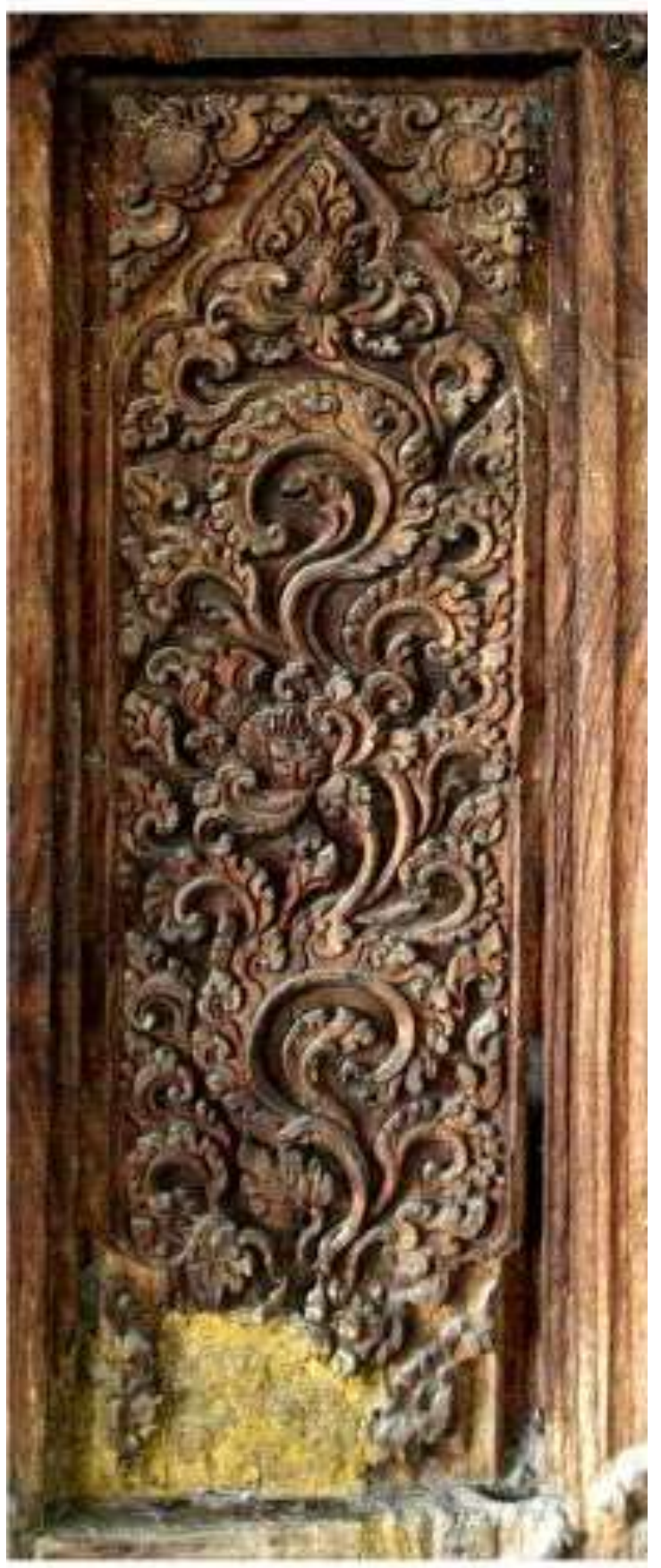



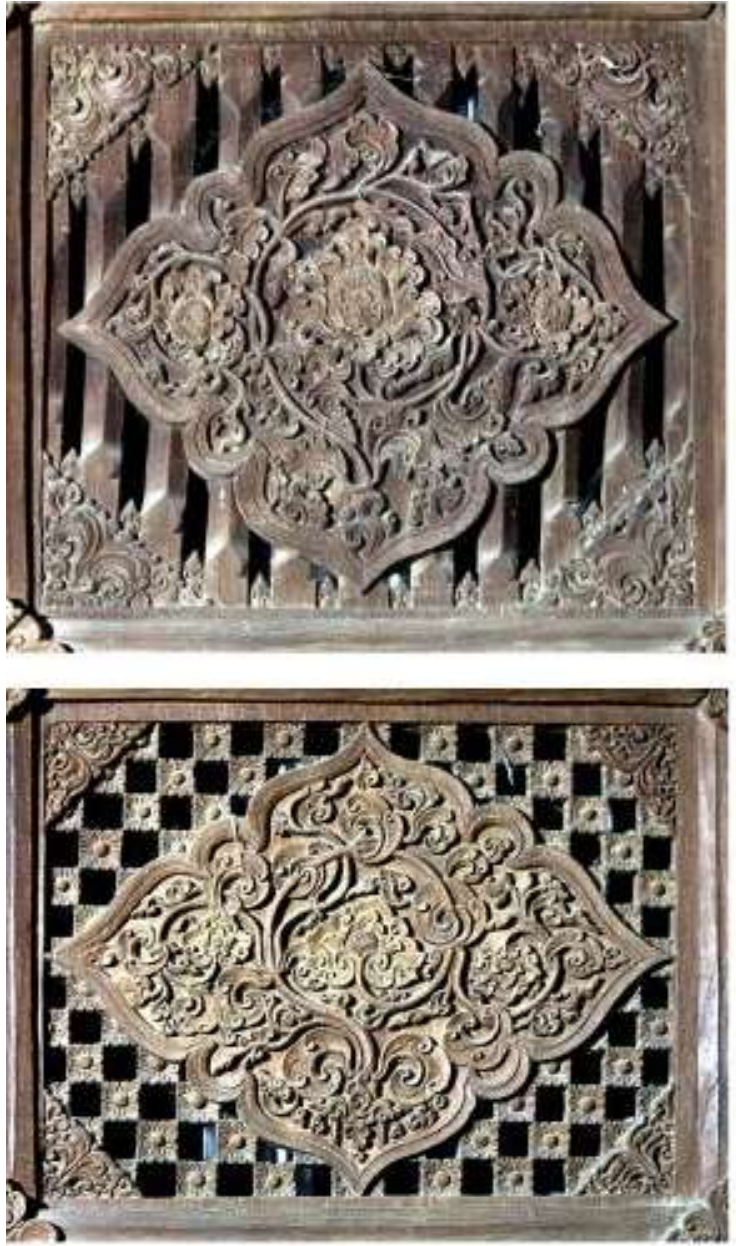

Gambar 3. Ragam hias sulur gelung teratai di kompleks makam Sunan Drajat, Lamongan Jawa Timur. (Foto Nizam 2018)

Ragam hias flora sulur gelung teratai secara mengesankan ditampilkan di mihrab (teratai tiga dimensi menggantung) dan mimbar khutbah lama Masjid Agung Cirebon, di kompleks masjid dan makam Sendang Duwur, di makam Sunan Drajat Lamongan Jawa Timur, Masjid Menara Kudus, kompleks masjid dan makam Mantingan Jepara, di pendapa dan mimbar khutbah masjid Agung Demak dan di kompleks makam Wali yang lain, akan tetapi jelas tanpa telaga, tanpa pentol, tanpa guci berlimpah, apalagi tumbuh dari pusar yaksa atau binatang. Itulah sebabnya, mengapa warisan ragam hias klasik Majapahit sampai saat ini tidak diketahui pangkal tumbuhnya, karena memang sengaja dihilangkan pada masa transisi agar tidak menyamai dengan ragam hias teratai padmamūla Hindu. Demikianlah, ragam hias flora gulungan teratai yang dikatakan oleh berbagai peneliti sebagai ragam hias tanaman yang aman dari sudut yurisprudensi Islam karena tidak menggambarkan makhluk yang bernyawa, ternyata menyimpan kerumitan teologis, yang jika tidak hati-hati mewujudkannya akan dianggap sama dengan simbol padmamūla Hindu, tidak lagi sabda Kun maka fa Yakun, Jadilah.

\section{PENUTUP}

Viabilitas ragam hias sulur gelung teratai, setelah mengalami perubahan evolutif dari motif padmamūla, kemudian menjadi motif tunjung tanpa telaga sangat mungkin menjelma menjadi sembilan gaya ragam hias klasik Jawa yang diwarisi kriyawan saat ini. Konsep penciptaannya didasari pemikiran ihwal kehidupan dan spiritual. Tujuan penciptaannya untuk memuliakan hidup. Visualisasinya tidak dapat menjadi indikator identitas ke-hinduan, ke-buddhaan atau keislaman.

Konsep seni yang diambil dari karya sastra yang diwujudkan dalam relief ragam hias merupakan proses menyesuaikan, membuat menjadi sesuai. Sulur gelung teratai yang gagasannya diambil dari kitab-kitab purana dapat dipandang sebagai 'tindakan adaptasi' karena melibatkan re-interpretasi, penciptaan kembali. Hal ini juga sama dengan konsep seni tunjung tanpa telaga, yang disebut-sebut dalam kitab-kitab sastra dan prosa Islam Jawa Pesisiran.

Setiap seniman berurusan dengan konsep dasar penciptaan dalam proses kreatifnya. Kasus semacam ini muncul ketika seniman harus mengubah suatu karya seni tertentu menjadi bentuk disiplin seni baru lainnya. Metode ini dilakukan dengan mengubah karya sastra menjadi bentuk seni visual. Sulur gelung teratai pada era Islam masa transisi, eksekusi bentuknya menjadi ambivalen, wujudnya mendua maka maknanya dapat bercabang 
dua. Secara visual bentuknya sekilas sama dengan motif gaya lama, namun sebenarnya berbeda maknanya. Hal ini menunjukkan bahwa sikap Islam yang inklusif terhadap simbol-simbol budaya, melibatkan tradisi intelektual yang dinamis, kreatif dan menunjukkan tingkat religiositas yang intens. Maka dari simbol yang sama, dapat dimaknai berbeda, karena pada dasarnya adaptasi adalah "... telling the same story from a different point of view" (Hutcheon, 2006, 8). Melalui reduksi bentuk, makna asal suatu ragam hias menjadi tidak dapat dimaknai sama seperti asalnya. Viabilitas dalam wujud baru dengan demikian memunculkan makna baru. Ini lah karya seni ragam hias Islam masa transisi yang berhasil mengintegrasikan nilainilai religios yang saling meninggikan dan memuliakan yang khas Jawa Islam.

\section{UCAPAN TERIMA KASIH}

Rasa terima kasih diucapkan kepada bapak H. Rahmat Dasy, kolektor naskah Jawa Pasisiran dari Kranji, Kec. Paciran, Lamongan Jawa Timur atas perkenan dan kebaikan beliau mengijinkan mengkaji bersama naskah-naskah langka.

\section{DAFTAR PUSTAKA}

Bosch, F.D.K. 1960. The Golden Germ: An Introduktion To Indian Symbolism. Terj. J.W. de Jong dan F.B.J. Kuiper, ed. Mouton \& Co.-'S-Gravenhage.

Coomaraswamy, Ananda K. 1931. Yaksas: Part II. Washington, D. C.: Smithsonian Institution Freer Gallery of Art.

Donder, I Ketut. 2007. Kosmologi Hindu: Penciptaan, Pemeliharaan, dan Peleburan Serta Penciptaan Kembali Alam Semesta. Surabaya: Paramita.

Fischer, Joseph. 1994. The Folk Art of Java. Kuala Lumpur: Oxford University Press.
Hadiwijono, Harun. 1971. Agama Hindu dan Agama Buddha. Djakarta: Badan Penerbit Kristen.

Hoop, A.N.J. Th. à Th. van der. 1949. Indonesische Siermotiven. Koninklijk Bataviaasch Genootschap van Kunsten en Wetenschappen.

Hutcheon, Linda. 2006. A Theory of Adaptation. New York: Routledge.

Kempers, A.J. Bernet. 1954. Tjandi Kalasan dan Sari. Terj. R. Soekmono Djakarta: Dinas Purbakala Republik Indonesia Penerbitan Dan Balai Buku Indonesia.

Kieven, Lydia. 2013. Following the Cap-Figure in Majapahit Temple Reliefs. LeidenBoston: Brill.

Kinney, Ann R. 2003. Worshiping Siva and Buddha: The Temple Art of East Java. Honolulu: University of Hawai i Press.

Krom, N. J. 1923. Hindoe-Javaansche Kunst. 'SGravenhage Martinus Nijhoff.

Muchtar, But. 1991. "Daya Cipta di Bidang Kriya" dalam Seni: Jurnal Pengetahuan dan Penciptaan Seni, Vol. I, No. 03 Oktober 1991: 9.

Sedyawati, Edi. 1992. "Seni: Mula Jadinya di Masa Lalu", Seni: Jurnal Pengetahuan dan Penciptaan Seni, Oktober, h.2.

2014. Kebudayaan di Nusantara: Dari Keris, Tor-Tor sampai Industri Budaya. Depok: Komunitas Bambu.

et al. 2013. Candi Indonesia: Seri Jawa. Direktorat Pelestarian Cagar Budaya dan Permuseuman, Kementerian Pendidikan dan Kebudayaan.

Soedarso Sp. 2006. Trilogi Seni, Penciptaan, Eksistensi, Dan Kegunaan Seni. Yogyakarta: Badan Penerbit Institut Seni Indonesia Yogyakarta. 
Sunarya, I Ketut. 2003. "Garis Lintang Penampang Kriya: Seni Refleksi Jiwa Zaman yang Ambigu", Imaji: Jurnal Seni dan Pendidikan Seni, Vol. I, No. 2 Agustus, h.199.

Zoetmulder, P. J. 2000. Manunggaling Kawula Gusti: Pantheisme dan Monisme dalam Sastra Suluk Jawa. Jakarta: PT Gramedia Pustaka Utama.

\section{Naskah Rujukan}

Nama naskah: Tariq Syaththariyah; Huruf: Arab Pegon; Bahasa: Jawa Pesisiran; Pemilik naskah: Syeh Rifa i; Asal naskah: Bungah-Gresik; Kolektor naskah: $\mathrm{H}$. Rahmat Dasy, dari Kranji, Paciran Lamongan Jawa Timur.

Nama naskah: Bayan Alim; Huruf: Jawa; Bahasa: Jawa Pesisiran; Pemilik naskah:
Moh. Tajid; Asal naskah: Kranji Paciran Lamongan; Kopi naskah dari $\mathrm{H}$. Rahmat Dasy, dari Kranji, Paciran Lamongan Jawa Timur.

Nama naskah: Anonim; Huruf: Khat Naski, Arab-Pegon, tinta hitam dan merah; Bahasa: Jawa Pesisiran; Genre: Prosa; Bahan: Kertas Gedog; Ukuran naskah: P: $29 \mathrm{~cm}$; L: $20 \mathrm{~cm}$; Tebal: $4 \mathrm{~cm}$; Jumlah halaman: 570/ halaman 21 baris, dijilid benang; Pemilik naskah: R. Edy Santosa bin R. Setyo Adji; Asal naskah: Rumah Ndalem Drajat Paciran, Lamongan; Isi naskah: Wejangan Syékh Majnūn kepada muridnya dan wejangan dari para Wali mengenai ilmu Tasawuf; Kopi naskah dari H. Rahmat Dasy, dari Kranji, Paciran Lamongan Jawa Timur. 